\title{
PH Domain
}

National Cancer Institute

\section{Source}

National Cancer Institute. PH Domain. NCI Thesaurus. Code C14077.

Pleckstrin-homology $(\mathrm{PH})$ domains are protein modules of approximately 120 amino acids found in a wide variety of signaling proteins in organisms ranging from yeast to humans. Some PH domains bind with high affinity (low mM or nM Kd) to specific phosphoinositides such as phosphatidyl-inositol (PI) -4,5-bisphosphate, PI-3,4-P2 or PI3,4,5-P3. Binding to phosphoinositides may allow PH proteins to respond to lipid messengers for example by relocation to membranes. The C-termini of some $\mathrm{PH}$ domains have also been reported to bind the beta/lambda subunits of heterotrimeric $\mathrm{G}$ proteins. 